University of Nebraska - Lincoln

DigitalCommons@University of Nebraska - Lincoln

1963

Two New Gyrodactylus (Trematoda: Monogenea) from Cyprinid Fishes with Synopsis of Those Found on North American Fishes

Glenn L. Hoffman

US Fish and Wildlife Services

Robert E. Putz

Bureau of Sport Fisheries and Wildlife, Kearneysville

Follow this and additional works at: https://digitalcommons.unl.edu/usfwspubs

Part of the Aquaculture and Fisheries Commons

Hoffman, Glenn L. and Putz, Robert E., "Two New Gyrodactylus (Trematoda: Monogenea) from Cyprinid Fishes with Synopsis of Those Found on North American Fishes" (1963). US Fish \& Wildlife Publications. 104.

https://digitalcommons.unl.edu/usfwspubs/104

This Article is brought to you for free and open access by the US Fish \& Wildlife Service at DigitalCommons@University of Nebraska - Lincoln. It has been accepted for inclusion in US Fish \& Wildlife Publications by an authorized administrator of DigitalCommons@University of Nebraska - Lincoln. 


\title{
Two New Gyrodactylus (Trematoda : Monogenea) from Cyprinid Fishes with Synopsis of Those Found on North American Fishes
}

\author{
Robert E. Putz and Glenn L. Hoffman \\ Bureau of Sport Fisheries and Wildlife, Kearneysville, West Virginia
}

\begin{abstract}
Gyrodactylus atratuli from the blacknose dace (Rhinichthys atratulus) and the pearl dace (Semotilus margarita) is compared with known species of Gyrodactylus from North American fishes and described as a new species.

Gyrodactylus margaritae from the pearl dace (Semotilus margarita) is compared with known species of Gyrodactylus from North American fishes and described as a new species.

The average number of $G$. atratuli per blacknose dace in the natural habitat is 7.8 ( 1 to 32 ) and in the laboratory at the same water temperature after 55 days in captivity, 5.4 ( 0 to 11$)$.

G. atratuli and G. margaritae fail to live and reproduce on fish kept in nonrunning water at between 19 and $26 \mathrm{C}$ in laboratory aquaria, but will live and reproduce in running spring water at $12 \mathrm{C}$ in laboratory aquaria.

An illustrated synopsis with a comparative table of measurements of known North American Gyrodactylus and a list of the species with brief reference to their differentiating characteristics are given.
\end{abstract}

During the summer of 1962, two species of fish, the blacknose dace (Rhinichthys atratulus) and the pearl dace (Semotilus margarita), from the south branch of Leetown Run, Leetown, West Virginia, harbored Gyrodactylus species on the body and fins. One species of Gyrodactylus was found on both the blacknose and the pearl dace, while another species was found only on the pearl dace. After comparison with known species of Gyrodactylus found on North American fishes, they are here described as new species, Gyrodactylus atratuli from both the blacknose and pearl dace, and Gyrodactylus margaritae from the pearl dace.

Following the new species descriptions is an illustrated synopsis of the genus Gyrodactylus and a comparative table showing the measurements in microns of known Gyrodactylus species found on North American fishes.

\section{MATERIALS AND METHODS}

Fish harboring the parasites were taken by seine from Leetown Run, which is spring fed with water $12 \mathrm{C}$ throughout the year.

For maintaining the parasites, the fish were kept in stainless-steel troughs with a small constant flow of spring water about the same temperature as the Leetown Run.

Received for publication 12 March 1963.
For obtaining the parasites for microscopy, fish were placed in petri dishes containing a solution of $1: 4,000$ formalin (modification of Parker and Haley, 1960). After a few minutes the parasites dropped to the bottom of the dishes and were pipetted to slides for study or fixed for permanent preparation.

The parasites were studied in living, fixed, and stained preparations. If permanent mounts were to be made, the parasites were changed from the $1: 4,000$ formalin solution to a $10 \%$ formalin solution for thorough fixing. Various stains were employed for permanent mounts, but Harris' hematoxylin was preferred. For studying temporary stained mounts, methyl green $(0.25 \%$ in $1.0 \%$ acetic acid) was used. A drop of this stain was placed on the slide at the edge of the cover slip and allowed to diffuse under. A progressive staining could be achieved with this method, and it was found to emphasize the cirrus pouch and its armature as well as other anatomical structures.

Gross measurements were made in the living state and also after the parasites had been removed with the 1:4,000 formalin solution. These measurements were made without the use of cover slips. Measurements of the more detailed anatomy were taken in the unstained and stained state, but with ample liquid beneath the cover slip to minimize distortion of the organism due to cover-slip pressure.

For studying the hard parts in detail, the soft body parts were allowed to decompose under a vaseline-sealed cover slip (Ikezaki and Hoffman, 1957).

All measurements (method of Malmberg, 1956) 


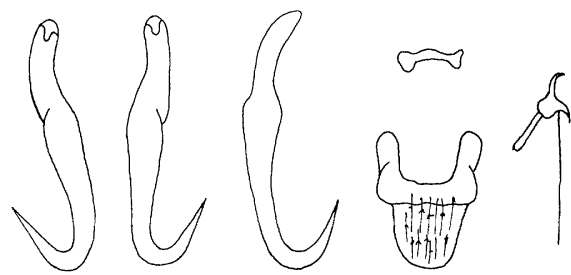

FIGURE 1. G. ATRATULI N. SP.

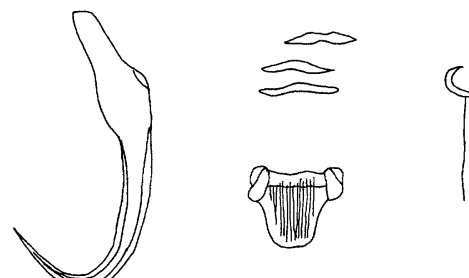

FIGURE 2. G. BAIRDI

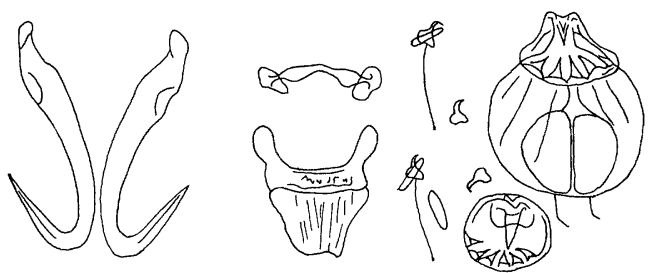

FIGURE 3. G. BULLATARUDIS

(-1i:

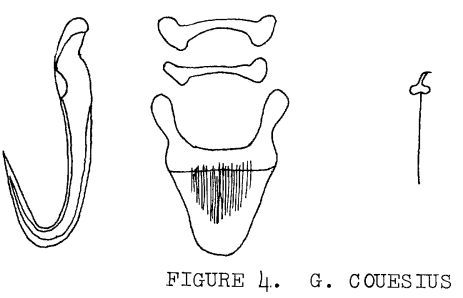

(atp

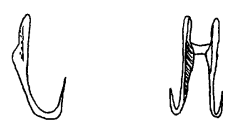<smiles>[C]1C#CC1</smiles>

FIGURE 5. G. CYL INDR I FORMIS

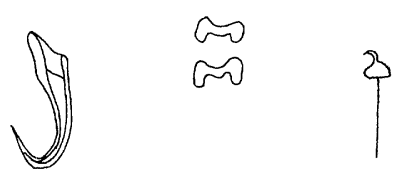

踏

FIGURE 6. G. EGREGIUS

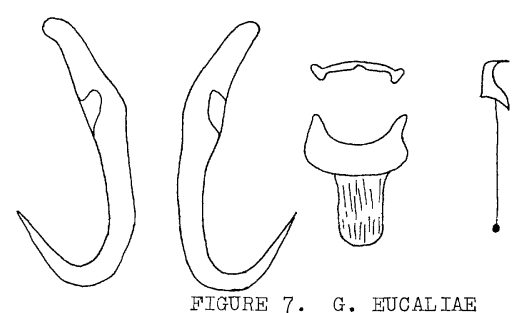

NA

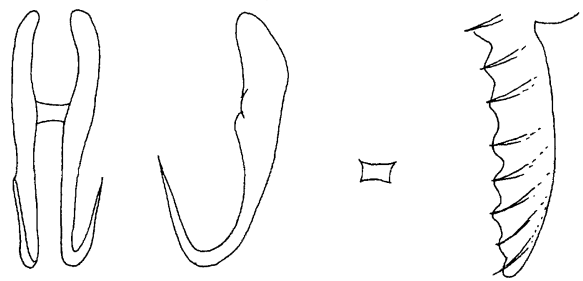

FIGURE 8. G. FAIRPORTI

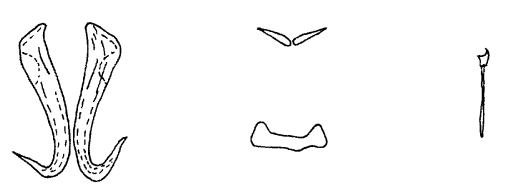

FIGURE 9. G. FUNDULI

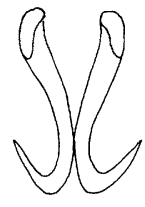<smiles>c1ccnnc1</smiles>

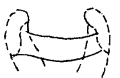

FIGURE 10. G. GURLEYI<smiles>C=C/C=C\C</smiles>

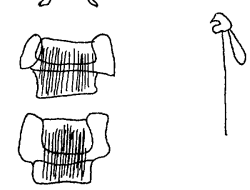

(20)

FIGURE 11. G. LIMI
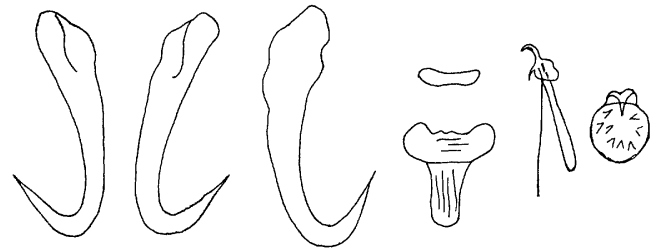

FIGURE 12. G. MARGARITAE N. SP.

Plate I

Figures 1 To 12. Hard parts of North American Gyrodactylus species redrawn from originals except Figures 1 and 12, which were drawn with the aid of microprojection and the marginal hook of Figure 7 which is original. 
are in microns and based on ten or more specimens The average is given with the range following in parentheses.

\section{Gyrodactylus atratuli sp. $\mathrm{n}$.} (Plate I, Fig. 1)

Description: Body large and cylindrical, greatest width slightly posterior to midregion, 414 (337 to 500 ) by 81 ( 74 to 94 ). Anchors stout, 62 ( 59 to 63) from base to point of greatest curvature. Length of point 28 ( 27 to 29 ). Width between anchor bases without cover-slip pressure, 43 ( 42 to 45 ). Dorsal bar length 18 (17 to 19 ). Width at midpoint 1.5 (constant) and resilient. Width at end 3 ( 2 to 4 ) with terminal bullae 8 ( 7 to 9 ). Ventral bar 28 ( 26 to 29 ) by 5 ( 5 to 6 ) with parallel anterior projections. Anterior projections from posterior margins to bluntly rounded ends 18 ( 16 to 19 ) by 5 ( 4 to 7 ). A concave area midway on outside edge of these anterior projections. Shield of ventral bar distinct in fresh preparations with longitudinal striations, 26 ( 23 to 27 ) wide at edge of ventral bar, tapering to 14 ( 10 to $15)$ in width at the distal end. Marginal hooklets 30 ( 28 to 31 ), total length including shaft 27 ( 25 to 28 ) and hook area 4 (3.5 to 4.5 ). Sixteen marginal hooklets constant for all parasites examined, and individual sizes constant for particular parasite. Hooklet accessory piece (lamella) tubular, U-shaped, 10.5 ( 10 to 11 ) long. Pharynx consists of two regions, the anterior bulb, 30 ( 25 to 36) in diameter, and the posterior bulb, 9 ( 8 to 14 ) in diameter, which leads into the nonbifurcated area of the intestine. Lateral and slightly posterior to the pharynx on each side is a pair of vesicular cephalic glands 21 (19 to 22) in diameter. Anterior of each pair directed ventrally, the posterior more dorsal. Globular vesicles in head lobes each terminate in an extrusible anterior spine approximately 3 in length. With cover-slip pressure, tubules could be seen within these globular head vesicles and running posteriorly from them, but their definite pattern, origin, and shape could not be determined. Ovary and egg enclosed in thin-walled ovarian sac just posterior to the uterus which usually contains an embryo. Vitelline glands paired, irregular, and posterolateral to the testis. Cirrus pouch 10 ( 9 to 12 ) in diameter, on left of the ventral midline just behind the pharynx, containing a ring 6 (6 to 7$)$ in diameter armed with one large "C"-shaped hook about 4 long and 6 small hooks about 2 long. Testis 30 ( 28 to 32 ), just posterior to ovary.

Host: Rhinichthys atratulus (Hermann) (blacknose dace) and Semotilus margarita (Cope) (pearl dace).

Location: Skin.

Locality: South branch of Leetown Run, Leetown, West Virginia.

Type: Eastern Fish Disease Laboratory.

Paratype: U. S. National Museum Helm. Coll. No. 59887.
Comparison: The most important criteria for distinguishing species of Gyrodactylus are the size, shape, and number of hard parts. These consist of the anchors, bars, hooklets, cirrus armature, and head organ spines. Turnbull (1956) notes that newly born Gyrodactylus do not have cirrus armature present. One species (G. prolongis) has a peduncle skirt whose edge is armed with cuticularized points. Table I lists the measurements of the known species of Gyrodactylus found in North America, including the present species.

Gyrodactylus atratuli most resembles $G$. bullatarudis, G. cylindriformis, G. eucaliae, and G. gurleyi, but differs from them in the following respects: G. bullatarudis has smaller anchors, a larger dorsal bar, thickened on either side of midline, and a larger cirrus pouch with the stylets varying from 4 to 7. G. cylindriformis lacks a dorsal bar. G. eucaliae has larger anchors and a straight and narrow dorsal bar notched at midpoint; Ikezaki and Hoffman (1957) described the cirrus pouch as having seven stylets and lacking a large spine, but we have examined paratypes and find six stylets and a larger spine. G. gurleyi has smaller anchors, ventral bar at the level of the proximal ends of the anchors, and no mention of a ventral shield. G. couesius has a similar anchor size but is smaller in total size, has a cirrus with eight stylets, and marginal hooklets with a bilobed base and no accessory piece.

\section{Gyrodactylus margaritae sp. $\mathrm{n}$.}

(Plate I, Fig. 12; Plate II, Fig. 13)

Description: Body small and cylindrical, 208 ( 237 to 287 ) by 82 ( 56 to 112 ). Opisthaptor discshaped with marginal hooklets completely around, 69 (62 to 73) (Plate II, Fig. 13). Anchors small, 35 ( 33 to 36 ) from base to point of greatest curvature. Length of point 9 ( 7 to 11$)$. Dorsal bar length 9 ( 8 to 11 ), width 2 ( 1.0 to 2.5 ) with slight narrowing at midpoint. Ventral bar 13 ( 11 to 14 ) by 4 ( 3.5 to 4.5 ). No lateral anterior projections and a rough appearance on the anterior edge. Ventral shield narrow 5 ( 4.5 to 5.5 ) by 9 ( 8 to 11 ), with longitudinal striations. Marginal hooklets 22 (20 to 23) total length, shaft 16 ( 14 to 17 ) with the hook area $6(5.5$ to 6.5$)$. Accessory piece (lamella) U-shaped, 12 (10 to 13) long. Pharynx consists of two regions: the anterior bulb, 37 ( 35 to 39 ) in diameter, and the posterior bulb 48 ( 47 to 51 ) in diameter. Cephalic gland areas lateral and posterior to pharynx. Their shape could not be verified, but they appeared triangular. 

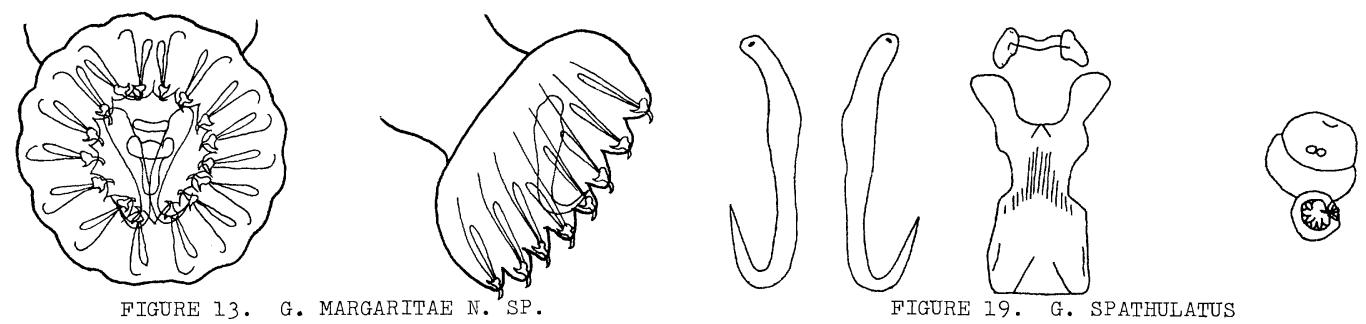

FIGURE 13. G. MARGARITAE N. SP.
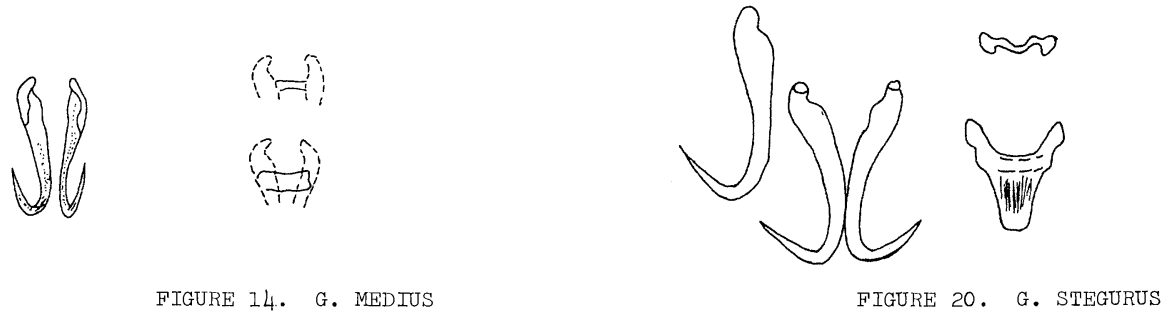

FIGURE 14. G. MEDIUS

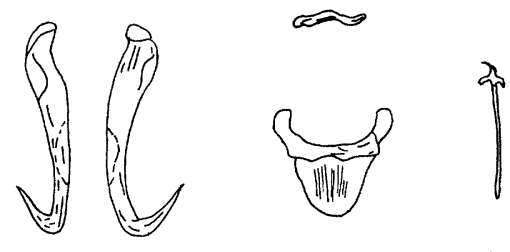

FIGURE 21. G. STEPHANUS

FIGURE 15. G. MICROPOGANS
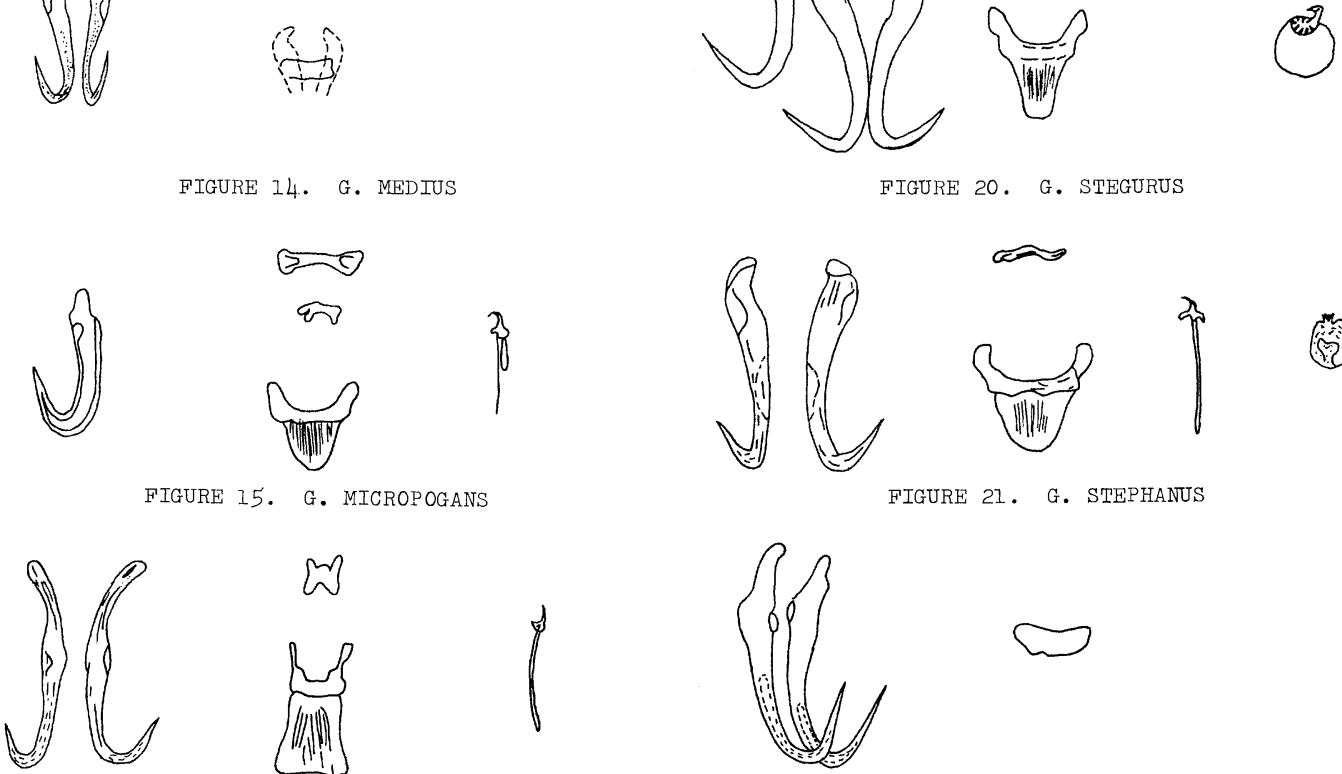

n

FIGURE 16. G. PROLONGIS

FIGURE 22. G. SP. OF HARGIS, 1953
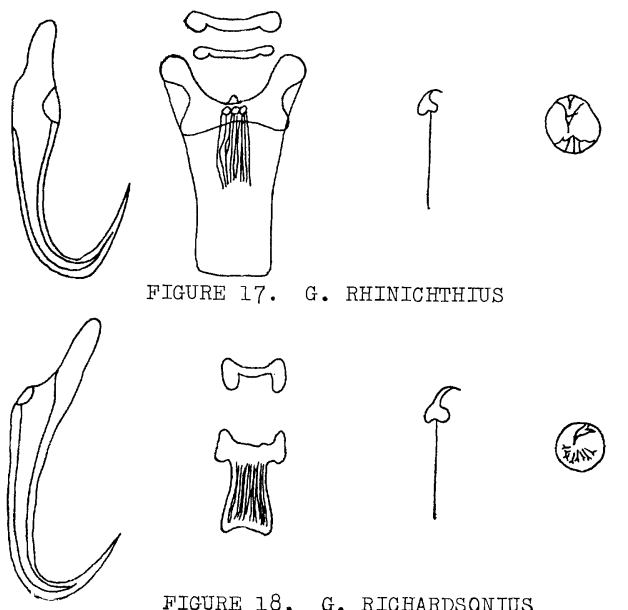

IGURE 17. G. RHINICHTHIUS
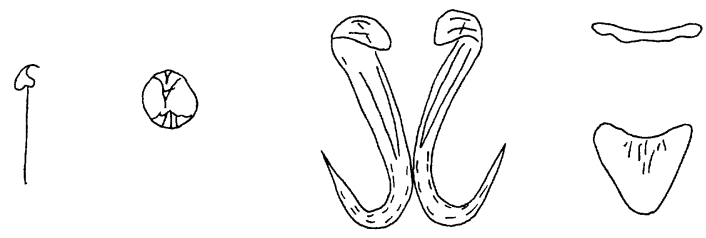

FIGURE 23. G. SP. OF HARGIS, 1955

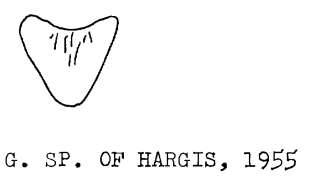

(P)

Plate II

Figures 13 то 23. Hard parts of North American Gyrodactylus species continued. Redrawn from originals, except Figure 13 which was drawn with the aid of microprojection. Figure 15 should read micropogonus. 
Globular vesicles lying in each head lobe terminate in anterior spines about 2 long. The definite shape and pattern of the vesicles could not be seen. Cirrus pouch 14 (12 to 15 ) in diameter, behind pharynx, containing a ring 7 (6 to 8 ) in diameter armed with one large hook and 8 smaller ones. Remainder of reproductive system not determined except uterus usually containing embryo.

Host: Semotilus margarita (Cope) (pearl dace).

\section{Location: Skin.}

Locality: South branch of Leetown Run, Leetown, West Virginia.

Type: Eastern Fish Disease Laboratory.

Paratype: U. S. National Museum Helm. Coll. No. 59886.

Comparison: Gyrodactylus margaritae most resembles G. funduli, G. egregius, and $G$. micropogonus, but differs from them in the following respects: G. funduli has a dorsal bar which is somewhat variable in shape and often appearing bipartite. The ventral bar has small anteriorly directed truncate ends and lacks a ventral shield. G. egregius lacks a ventral bar and shield. G. micropogonus has a large and variable dorsal bar. The papilla in the cephalic head lobes possess two or three cuticular spines and the cirrus is smaller with the details not described.

\section{BIOLOGICAL OBSERVATIONS}

Host specificity: G. atratuli was found on both the blacknose and pearl dace while $G$. margaritae was found only on the pearl dace. Neither G. atratuli or G. margaritae were found on Lepomis cyanellus, L. macrochirus, Micropterus salmoides, or Carassius auratus from the same water. Malmberg (1956) found only one Gyrodactylus species, G. wageneri scardinii, which had two different species of fish as hosts, and feels there is a possibility here of a physiological subspecies. Bychowsky (1957) lists two Gyrodactylus species, G. medius and G. fairporti, having two different species of fish as hosts, but feels these are mistakes.

Host-specificity experiment: One species of Gyrodactylus is usually found on only one species of fish in nature (Malmberg, 1956). In fish culture, however, they may be more or less accidental parasites on closely related fishes (Hoffman and Putz, 1963). Since G. atratuli is herein recorded from two genera of one family of cyprinid fishes, the following experiment was performed to determine whether the Gyrodactylus from both fishes are identical.
All experiments were conducted in steel troughs with running spring water at $12 \mathrm{C}$. Noninfected fish were obtained by removing their ectoparasites with a 30-min formalin treatment ( $1: 4,000$ for the blacknose dace, $1: 6,000$ for the pearl dace).

Trough A-Five infected blacknose dace + five noninfected pearl dace.

Trough B-Five infected blacknose dace + five noninfected fin-clipped blacknose dace.

Trough C-Five infected pearl dace + five noninfected blacknose dace.

Trough D-Five infected pearl dace + five noninfected fin-clipped pearl dace.

After 2 weeks the number of Gyrodactylus per fish was counted in each trough using the method previously described with the results as follows: In trough $\mathrm{A}$, the five infected blacknose dace harbored an average of eight $G$. atratuli per dace; of the noninfected pearl dace, one was found with one G. atratuli. Trough B (control for trough A) showed an average of 4.8 G. atratuli per infected blacknose dace, and an average of 4.2 per noninfected finclipped blacknose dace. Trough $\mathrm{C}$ showed an average of nine G. atratuli per infected pearl dace, and none for the noninfected blacknose dace. Trough $\mathrm{D}$ (control for trough $\mathrm{C}$ ) showed an average of five G. atratuli per infected pearl dace and an average of six G. atratuli per noninfected fin-clipped pearl dace.

These results would support Malmberg's (1956) views and suggest the possibility that G. atratuli consists of two physiological species.

Intensity of infection: G. atratuli were removed from 20 blacknose dace and counted the same morning after seining in order to determine the number of parasites per fish in the natural habitat. These fish in their natural habitat were found to be infected with an average of 7.8 ( 1 to 32 ) parasites per fish. The same number of fish were held in the laboratory in $12 \mathrm{C}$ water for 55 days. Their parasites were then removed and counted in order to determine if captivity at the same water temperature as their natural habitat would alter the parasite number. An average of 5.4 (0 to 11) parasites were recovered. Fish from this lot were also held in aquaria with nonrunning water at temperatures ranging from 19 to $26 \mathrm{C}$, 
TABle I. North American Gyrodactylus, measurements in microns. All compiled from the original description except G. atratuli sp. $n$. and G. margaritae $s p$. n., which are original.

\begin{tabular}{|c|c|c|c|c|c|c|c|c|}
\hline Species & Host & Body & Anchor & Dorsal bar & Ventral bar & $\begin{array}{l}\text { Ventral } \\
\text { shield }\end{array}$ & $\begin{array}{l}\text { Marginal } \\
\text { hooklets }\end{array}$ & $\begin{array}{c}\text { Cirrus } \\
\text { pouch } \\
\text { diameter }\end{array}$ \\
\hline $\begin{array}{l}\text { G. atratuli } \\
\text { sp. n. }\end{array}$ & $\begin{array}{l}\text { Rhinichthys } \\
\text { atratulus, } \\
\text { Semotilus } \\
\text { margarita }\end{array}$ & $414 \times 81$ & $\begin{array}{c}62 \\
\text { point } 28\end{array}$ & $18 \times 1.5$ & $\begin{array}{l}28 \times 5 \\
\text { anterior } \\
\text { proj. } 18\end{array}$ & $19 \times 26$ & $\begin{array}{lr}\text { shaft } & 27 \\
\text { hook } & 4\end{array}$ & 10 \\
\hline G. bairdi & $\begin{array}{l}\text { Cottus } \\
\text { b. bairdi }\end{array}$ & $368 \times 72$ & 68 & length 16 & 24 & - & hook & 9 \\
\hline G. bullatarudis & $\begin{array}{l}\text { Lebistes } \\
\text { reticulatus }\end{array}$ & $405 \times 68$ & $\begin{array}{c}52 \\
\text { point } 24\end{array}$ & $23 \times 1.0$ & $\begin{array}{l}23 \times 5 \\
\text { anterior } \\
\text { proj. } 15\end{array}$ & length 14 & $\begin{array}{l}\text { shaft } 20 \\
\text { hook } 5\end{array}$ & 12 \\
\hline G. couesius & $\begin{array}{l}\text { Couesius } \\
\text { plumbius } \\
\text { dissimilis }\end{array}$ & $314 \times 90$ & 61 & length 26 & length 35 & - & total 31 & - \\
\hline G. cylindriformis & Umbra limi & $450 \times 50$ & 60 & 一 & 一 & - & 一 & - \\
\hline G. egregius & $\begin{array}{l}\text { Richardsonius } \\
\text { egregius }\end{array}$ & $296 \times 116$ & 33 & 9 & absent & - & hook & 11 \\
\hline G. eucaliae & $\begin{array}{l}\text { Eucalia } \\
\text { inconstans }\end{array}$ & $445 \times 88$ & 69 & $\begin{array}{c}18-34 \\
\times 2\end{array}$ & $\begin{array}{c}26-31 \\
\times 7\end{array}$ & $\begin{array}{r}18-20 \\
\times 17-19\end{array}$ & $\begin{array}{lr}\text { shaft } & 35 \\
\text { hook } & 9\end{array}$ & $10-14$ \\
\hline G. fairporti & $\begin{array}{l}\text { Ameriurus } \\
\text { melas, } \\
\text { Cyprinus } \\
\text { carpio }\end{array}$ & $\begin{array}{r}350-450 \\
\times 50-75\end{array}$ & $53-65$ & 一 & - & - & total $20-30$ & 一 \\
\hline G. funduli & $\begin{array}{l}\text { Fundulus } \\
\text { similis }\end{array}$ & $261 \times 51$ & $32 \times 8$ & $10 \times 1.0$ & $12 \times 3$ & - & total 21 & - \\
\hline G. gurleyi & $\begin{array}{l}\text { Carassius } \\
\text { auratus }\end{array}$ & $\begin{array}{r}435-510 \\
\times 60-76\end{array}$ & $45-49$ & - & - & - & total 23 & 一 \\
\hline G. limi & Umbra limi & $612 \times 116$ & 68 & 22 & 16 & - & total 37 & 12 \\
\hline $\begin{array}{l}\text { G. margaritae } \\
\text { sp. n. }\end{array}$ & $\begin{array}{l}\text { Semotilus } \\
\text { margarita }\end{array}$ & $268 \times 82$ & $\begin{array}{c}35 \\
\text { point } 9\end{array}$ & $9 \times 2$ & $13 \times 4$ & $5 \times 9$ & $\begin{array}{lr}\text { shaft } & 16 \\
\text { hook } & 6\end{array}$ & 14 \\
\hline G. medius & $\begin{array}{l}\text { Micropterus } \\
\text { dolomieu, } \\
\text { Salvelinus } \\
\text { fontinalis }\end{array}$ & - & - & - & - & - & - & - \\
\hline G. micropogonus & $\begin{array}{l}\text { Micropogon } \\
\text { undulatus }\end{array}$ & $296 \times 108$ & 38 & 20 & 16 & - & hook & 10 \\
\hline G. prolongis & $\begin{array}{l}\text { Fundulus } \\
\text { grandis }\end{array}$ & $348 \times 76$ & $75 \times 10$ & $11 \times 7$ & $19 \times 6$ & - & total 41 & 10 \\
\hline G. rhinichthius & $\begin{array}{l}\text { Rhinichthys } \\
\text { csculus } \\
\text { robustus }\end{array}$ & $260 \times 90$ & 57 & 24 & 23 & - & hook 8 & - \\
\hline G. richardsonius & $\begin{array}{l}\text { Richardsonius } \\
\text { egregius }\end{array}$ & $\begin{array}{r}224-386 \\
\times 90-108\end{array}$ & $70-72$ & 24 & 18 & - & hook 9 & 14 \\
\hline G. spathulatus & $\begin{array}{l}\text { Catostomus } \\
\text { commersonnii }\end{array}$ & 500 & 120 & 一 & 一 & - & - & 27 \\
\hline G. stegurus & $\begin{array}{l}\text { Fundulus } \\
\text { diaphanus }\end{array}$ & $310 \times 75$ & 47 & - & 21 wide & 一 & total 26 & 18 \\
\hline G. stephanus & $\begin{array}{l}\text { Fundulus } \\
\text { heteroclitus, } \\
\text { F. grandis }\end{array}$ & $328 \times 44$ & $42 \times 7$ & $16 \times 1.0$ & $20 \times 4$ & - & - & 8 \\
\hline $\begin{array}{l}\text { G. sp. of } \\
\text { Hargis, } 1953\end{array}$ & $\begin{array}{l}\text { Ameiurus } \\
\text { n. nebulosus }\end{array}$ & $371 \times 71$ & 49 & absent & 15 & - & - & - \\
\hline $\begin{array}{l}\text { G. sp. of } \\
\text { Hargis, } 1955\end{array}$ & $\begin{array}{l}\text { Cyprinodon } \\
\text { variegatus }\end{array}$ & $287 \times 64$ & $40 \times 7$ & $23 \times 1.0$ & $24 \times 5$ & - & total 24 & - \\
\hline
\end{tabular}

and upon examination, not a single Gyrodactylus was found on any of the fish. This loss and nonreproduction of G. atratuli may be due to the unfavorable water temperature, the accumulation of metabolic products, a greater immune response of the host at warmer temperatures, or other unknown factors.

The above experiments were not performed with the pearl dace.

Pathogenicity: No mortality or evidence of 
irritation due to the presence of the Gyrodactylus was observed in either species of fish in the natural habitat or while in captivity.

\section{ILLUSTRATED SYNOPSIS OF THE GENUS \\ Gyrodactylus FOUND ON NORTH \\ AMERICAN FISHES}

(Plates I and II, Table I)

The object of this review is to bring together the drawings and information necessary for the identification of the known Gyrodactylus of fishes in North America.

Drawings shown in Plates I and II were traced from original papers except for $G$. atratuli and G. margaritae and the hooklets of G. eucaliae, which are originals. Measurements and hosts are given in Table I. Following is a list of the species, hosts, and geographic location with brief reference to their differentiating characteristics:

G. atratuli.-Rhinichthys atratulus (Hermann), south branch of Leetown Run, Jefferson County, West Virginia (this paper). Lateral projections of ventral bar same length as dorsal bar. Dorsal bar with terminal bullae at ends.

G. bairdi Wood and Mizelle, 1957.-Cottus b. bairdi (Girard), Judy Creek, St. Joseph County, Indiana (Wood and Mizelle, 1957). No anteriorly directed lateral projections of ventral bar. Vitellaria posttesticular.

G. bullatarudis Turnbull, 1956.-Lebistes reticulatus (Peters), laboratory reared (Turnbull, 1956). Dorsal bar thickened on either side of midline, stylets of cirrus pouch vary from 4 to 7 .

G. couesius Wood and Mizelle, 1957.-Couesius plumbius dissimilis (Girard), Loon Lake, British Columbia, Canada (Wood and Mizelle, 1957). Marginal hooklet base bilobed and no accessory piece (lamella).

G. cylindriformis Mueller and Van Cleave, 1932. -Umbra limi (Kirtland), Oneida Lake, New York (Mueller and Van Cleave, 1932). Dorsal bar absent. Large pharynx $40 \mu$ in diameter.

G. egregius Wood and Mizelle, 1957.-_Richardsonius egregius (Girard), Lahotan Reservoir, Reno, Nevada (Wood and Mizelle, 1957). Ventral bar absent. Marginal hooklets have subtriangular base. Cirrus with 8 stylets.

G. elegans Nordmann, 1832.-This confusing European species was reported from trout and goldfish by Mueller (1936a) and bluegill by Hargis (1953). The species is being revised by Malmberg (1962); therefore, we have not included it in this study.

G. eucaliae Ikezaki and Hoffman, 1957.-Eucalia inconstans (Kirtland), English Coulee, Grand Forks, North Dakota (Ikezaki and Hoffman, 1957 ). Dorsal bar straight and narrow with a simple notch at midpoint. The original description is here cor- rected-the cirrus pouch is $13 \mu$ in diameter and possesses one larger spine and eight small stylets. The marginal hooklets which we have redrawn are sickle-shaped, $9 \mu$ long with a $35-\mu$ shaft.

G. fairporti Van Cleave, 1921.-Ameiurus melas (Rafinesque) and Cyprinus carpio (Linnaeus), Fairport, Iowa (Van Cleave, 1921). Dorsal bar absent.

G. funduli Hargis, 1955._-Fundulus similis, Franklin County, Florida (Hargis, 1955). Obliquely truncated roots. Cirrus with one large spine and probably smaller ones.

G. gurleyi Price, 1937.-Carassius auratus (Linnaeus), Texas (Price, 1937). No mention of a ventral shield. Ventral supporting bar at the level of the proximal ends of the anchors.

G. limi Wood and Mizelle, 1957.-Umbra limi (Kirtland), Judy Creek, St. Joseph County, Indiana (Wood and Mizelle, 1957). Also reported by Peckham and Dineen (1957). Largest in length of any known North American species. Dorsal bar horseshoe-shaped. Ventral shield extending to anterior tips of ventral bar.

G. margaritae.-Semotilus margarita (Cope), south branch of Leetown Run, Jefferson County, West Virginia (this paper). Opisthaptor discshaped with marginal hooklets completely around. Accessory piece (lamella) almost as long as shaft. No lateral anterior projections of ventral bar.

G. medius Kathariner, 1894.-Micropterus dolomieu (Lacépède) and Salvelinus fontinalis (Mitchill). Reported in North America, but the validity of the identification is questioned by Price (1937). Also reported from Maine by Meyer (1954).

G. micropogonus Wood and Mizelle, 1957.Micropogon undulatus (Linnaeus), Aransas Pass, Texas (Wood and Mizelle, 1957). Marine. Dorsal bar variable. Papillae in cephalic lobes have two or three cuticular spines.

G. prolongis Hargis 1955 (syn. Gyrodactylus sp. of Linton, 1940).-Fundulus grandis Baird and Girard, Franklin County, Florida (Hargis, 1955). Peduncle unusual, surrounded by an anteriorly directed skirt whose edge is armed by several cuticularized points.

G. rhinichthius Wood and Mizelle, 1957.Rhinichthys osculus robustus (Rutter), Lahotan Reservoir, Reno, Nevada (Wood and Mizelle, 1957). Dorsal bar terminates in knoblike structures. Ventral shield extends to proximal portion of anchor points.

G. richardsonius Wood and Mizelle, 1957.Rhinichthys osculus robustus (Rutter), Lahotan Reservoir, Reno, Nevada (Wood and Mizelle, 1957). Ventral bar modified into a flat, finely striated plate. Ventral bar projections short. Dorsal bar rounded on each end into a posteriorly directed process.

G. spathulatus Mueller, 1936.-Catostomus commersonnii (Lacépède), Ithaca, New York (Mueller, 1936a). Also reported by Krueger (1954). Definite spatula-shaped ventral shield.

G. stegurus Mueller, 1937.-Fundulus diaphanus (LeSueur), Constantia, New York (Mueller, 1937). 
V-shaped dorsal bar with knob structures on each end. Ventral bar has anterolateral lobes.

G. stephanus Mueller, 1937.-Fundulus heteroclitus (Linnaeus), Baltimore, Maryland (Mueller, 1937). Fundulus grandis Baird and Girard, Alligator Harbor, Florida (Hargis, 1955). A redescription.

G. sp. Hargis, 1953.-Ameiurus n. nebulosus (LeSueur), Westhampton Lake, University of Richmond campus (Hargis, 1953). Specimens in poor condition, accurate identification impossible. Five specimens studied.

G. sp. Hargis, 1955.-Cyprinodon variegatus (Lacépède), Alligator Harbor, Franklin County, Florida (Hargis, 1955). One specimen studied. Abrupt medial curvature of anchor roots.

\section{ACKNOWLEDGMENTS}

The authors wish to thank Messrs. Colin Dunbar and Erwin W. Steucke of this laboratory for technical assistance.

\section{LITERATURE CITED}

Bychowsky, B. E. 1957. Monogenetic trematodes, their systematics and phylogeny. Acad. Sci. USSR, 481 p. (English translation by AIBS, 1961.)

Hargis, W. J. 1953. Monogenetic trematodes of Westhampton Lake fishes. III. Part 1. Comparative morphology of the species encountered. J. Parasit. 39: 88-105.

—. 1955. Monogenetic trematodes of Gulf of Mexico fishes. Part 1. The superfamily Gyrodactyloidea. Biol. Bull. 108: 125-137.

Hoffman, G. L., and R. E. Putz. 1963. Research in progress.

IKeZaKI, F. M., aNd G. L. Hoffman. 1957. Gyrodactylus eucaliae n. sp (Trematoda: Monogenea) from the brook stickleback, Eucalia inconstans. J. Parasit. 43: 451-455. Krueger, R. F. 1954. A survey of the helminth parasites of fishes from Van Buren Lake and Rocky Ford Creek, Ohio. J. Sci. 54: 277-279. Malmberg, G. 1956. On the presence of Gyrodactylus in Swedish fishes with description of species and a summary in English. Särtryck ur skrifter utgiva av södra sveriges fiskeriförening årsskrift. 20-78. (Partial English translation by U. S. Fish and Wildlife Service, 1962.) - 1962. Personal communication.

Meyer, M. C. 1954. The larger animal parasites of the freshwater fishes of Maine. State of Maine Dept. of Inland Fisheries and Game, Fishery Research and Management Division, Bull. No. 1.

Mueller, J. F. 1936a. Studies on North American Gyrodactyloidea. Trans. Am. Micr. Soc. 55: $457-464$.

- 1937. Further studies on North American Gyrodactyloidea. Am. Midl. Nat. 18: 207-219.

- aNd H. J. Van Cleave. 1932. Gyrodactylus cylindriformis new species. Roosevelt Wildlife Annals 3: 74-154.

Parker, J. C., ANd A. J. Haley. 1960. Methods for determination of the number of gyrodactylid trematodes parasitizing the skin of goldfish. J. Parasit. 40: 417.

Price, E. W. 1937. North American monogenetic trematodes. I. The superfamily Gyrodactyloidea. J. Wash. Acad. Sci. 27: 114-130.

Turnbull, E. R. 1956. Gyrodactylus bullatarudis n. sp. from Lebistes reticulatus Peters, with a study of its life cycle. Can. J. Zool. 34: 583-594.

Van Cleave, H. J. 1921. Notes on two genera of ectoparasitic trematodes from fresh-water fishes. J. Parasit. 8: 33-37.

Wood, R. A., ANd J. D. Mrzelle. 1957. Studies on monogenetic trematodes. XXI. North American Gyrodactylinae, Dactylogyrinae and a new host record for Urocleidus dispar (Mueller, 1936). Am. Midl. Nat. 57: 184202. 